\title{
CAUSES OF DELAY IN INDIAN TRANSPORTATION INFRASTRUCTURE PROJECTS
}

\author{
S.K. Patil ${ }^{1}$, A.K.Gupta ${ }^{2}$, D. B. Desai ${ }^{3}$, A.S.Sajane ${ }^{4}$ \\ ${ }^{1,4}$ Asst. Professor, ${ }^{2}$ Prof. \& Vice-Principal, ${ }^{3}$ Assoc. Prof. \& H.O.D. Civil, Dr. J. J. Magdum College of Engg, Jaysingpur, \\ Maharashtra, India \\ patilsuru@gmail.com,gupta7962@gmail.com,dbdesai1008@yahoo.co.in, samit.8146@gmail.com
}

\begin{abstract}
A survey on time performance of different types of construction projects in western Maharashtra was conducted to determine the causes of delay and their importance according to each of the project participants, i.e., the owner, consultant and the contractor. Sixty four causes of delay were identified during the research. It seems that the problem is common and notable as $72 \%$ of the total infrastructure projects reported by all the respondents were delivered late, whereas only $28 \%$ were completed on time. Clients' respondents indicated that 59\% of the public projects they were involved in were delivered late. Consultants' respondents reported that $62 \%$ of the projects they were involved in were completed late. Contractors' respondents also share the same view and articulated that $77 \%$ of the projects they are involved in exceeded the preset duration. The top five important causes of construction delays in transportation infrastructure projects are mainly Land Acquisition, Environmental Impact of the project, financial closure, Change orders by the client, Poor site management and supervision by contractor .Respondent's opinion about the contribution towards the delay is $50 \%$ respondent feels that delay in the construction in mainly due to the contractor. $40 \%$ of respondent feel that client is mainly responsible for the delay in construction projects. And only $10 \%$ of respondent feel that delay mainly occur due to consultant. It is evident that consultant as a mediator has less responsibility in construction delays.
\end{abstract}

Keywords: Transportation infrastructure projects; Construction delays; Questionnaire survey; Relative importance index. ****

\section{INTRODUCTION}

Completing projects on time is an indicator of efficiency, but the construction process is subject to many variables and unpredictable factors, which result from many sources. These sources include the performance of parties, resources availability, environmental conditions, involvement of other parties, and contractual relations. However, it is rarely happen that a project is completed within the specified time. The recently completed Bandra-Worli sea link amply demonstrates the state of project delivery system in the country. What was planned as a Rs 300 crore project to be completed by 2004 has actually cost Rs 1,600 crore along with a delay of five years. Indeed, very few projects get delivered in time and on cost. The quarterly reports of the Ministry of Statistics and Programme Implementation (MOSPI) stand testimony to a saga of unfettered delays and cost overruns, which have become the hallmark of infrastructure projects in India.

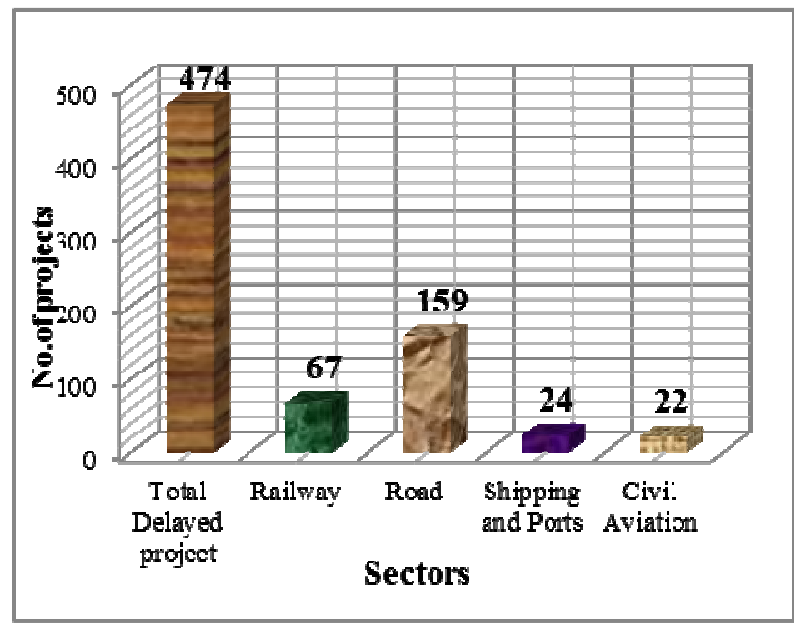

Chart-1 Delays in Transportation Infrastructure Projects

Yet, the extent and causes behind these time and cost overruns remain understudied. Out of a total of 951 on monitor, there are 146 projects without approved completion schedules. 195 projects do not have anticipated dates of Completion (DOC). The major chunk of these projects i.e. 122 are in the Railways sector. Also, having a further look at the statistics shows that in the delayed projects category, the major chunk is that of the 
Road Transport and Highways sector followed by the Railways sector. This is a concerning statistic which shows that transportation infrastructure projects are basically laggards in the overall infrastructure development in the country. Time and cost overruns have been a major problem affecting the central sector projects.

\section{OBJECTIVES OF STUDY}

The main objectives of this study include the following:

1. To identify the causes of delays in construction industry in India.

2. To test the importance of the causes of delay between parties involved in project.

3. To study the differences in perceptions of the three major parties in any constructions, namely, owners, contractors and consultants.

\section{LITERATURE REVIEW}

Ayman H.Al-Momani (2000) [1] studied, "Construction delay: a quantitative analysis". They concluded that, construction delay and cost overrun is a critical function in construction of public projects. It has been of great interest to construction researchers but has not been well understood in the case of public projects. Practically oriented research is vital for proper man-agreement of construction projects. Reliable prediction of construction duration and then controlling cost within budget is widely used in decision making and is an essential part of successful management. They concluded that, the main causes of delay in construction of public projects relate to designers, user changes, weather, site conditions, late deliveries, economic conditions and increase in quantity.

Daniel W M Chan and Mohan M. Kumaraswamy (1997) [2] investigated on, "A comparative study of causes of time overrun in Hong Kong construction projects". Results indicate that, the five principal and common causes of delays are: 'poor site management and supervision', 'unforeseen ground conditions', 'low speed of decision making involving all project teams', 'client-initiated variations' and 'necessary variations of works'. The relationship between success on site and 'strong' management teams underlines the need for effective site management and supervision by contractors and consultants. Manpower at both the technical and the managerial levels should have their own knowledge, updated by continuous professional development schemes. This may be in the form of short training programmes or day release courses in educational establishments. Kumaraswamy and Chan studied the causes of construction delays in Hong Kong. They found that there was a difference in perceptions as to causes of delays by different groups of participants in building and civil engineering works. They suggested that biases of different industry groups might direct blame for delays to other groups.
Noulmanee et al. [3] investigated causes of delays in highway construction in Thailand and concluded that delays can be caused by all parties involved in projects; however, main causes come from inadequacy of sub-contractors, organization that lacks of sufficient resources, incomplete and unclear drawings and deficiencies between consultants and contractors. The study suggested that delay can be minimized by discussions that lead to understanding.

Ubaid [4] discussed the performance of contractors as bone of the major causes of delay. Thirteen (13) major measures were considered. These measures are related to contractor resources and capabilities. Study concluded that lack of experience, poor estimation practices, bad decisions in regulating company's policy, and national slump in the economy are the severe factors.

Ram Singh, special article Economic and political Weekly (2010) [5] concluded on, "Delays and Cost Overruns in Infrastructure Projects: Extent, Causes and Remedies". He found that, delays are one of the crucial causes behind the cost overruns. Bigger projects have experienced much higher cost overruns compared to smaller ones. Compared to other sectors, projects in road, railways, urban-development sectors, as well as those in civil aviation, shipping and ports, and power sectors have experienced much longer delays. Analysis shows that, due to imperfect techniques and contractual incompleteness some delays and cost overruns are inevitable. However, delays are too frequent and too large to be accounted for by imperfect techniques, contractual incompleteness and inflationary fluctuations.

\section{RESEARCH METHODOLOGY}

Research methodology is carefully designed after assessing the extent of the objectives to be fulfilled. The questionnaire was believed to be the best technique for gathering the required data. The questionnaire has designed and distributed to the Government clients that are in charge of executing public projects, companies, contractors and their consultants that are supervising these projects. The research questionnaire contained: Sixty Four Causes delay were identified through literature review and discussion with some parties involved in construction industry. A questionnaire was developed in order to evaluate the severity and importance of the identified causes.

\section{DATA ANALYSIS}

The questionnaire is designed carefully to obtain the required data from the respondent that serves to achieve the research objectives. The present status of transportation projects and construction industry together with the findings of the literature review were used to form the questionnaire. Some questionnaires that are related to the topic were reviewed and some questions that are believed to be applicable to the 
construction industry were extracted from them. The main data required for this research is divided into three main categories. The first and second category is the information about the respondent's characteristics and their involvement in the construction industry. Questions concerning the performance of the projects that respondent has been involved in. This section identifies the number of projects that respondent has participated in and how many of them were delayed and what the average delay times were. It also has questions about the average delay that was let pass by clients, the party responsible for the delay along with effect of delay with five point scales and overall effect of delay. The third one concerns respondent's opinions on the severity of certain causes of delays transportation infrastructure projects. The third section contains the sixty four delay causes which has divided into three stages i.e Feasibility and early planning, Project planning and main procurement, Contract execution, monitoring and control etc. Therefore, it is important to identify the degree to how much the respondents agree or disagree on the severity of these causes based on their own experience and knowledge. To achieve this, a rating scale was designed which consists of 5-point scale. The range of weighting in the research survey scaled from 1 to 5 , as shown below.

(1). Not Significant (N.S.) 0\% delay contributing factors; (2) Slightly Significant (S.S.) <35\% delay contributing factors; (3) Moderately Significant (M.S.) 35-60\% delay contributing factors; (4) Very Significant (V.S.) 60-75\% delay contributing factors; (5) Extremely Significant (E.S.) $>75 \%$ delay contributing factors. The collected data were analyzed through the statistical techniques and indices. Following formula is used for calculating the 'Relative Importance Index' (RII) for different causes

$$
\text { Relative Importance Index (RII) }=\frac{\Sigma W}{A \times N}
$$

Where, $\quad 0 \leq \mathrm{RII} \leq 1$

$\mathrm{W}=$ Weighting given to each cause by respondent ranges from 1 to 5 where ' 1 ' is not significant and ' 5 ' is extremely significant , $A=$ Highest weight i.e. ' 5 ' in this case , $N=$ Total No. of respondents

Identified Causes are classified into five groups depending upon their Relative Importance Index (RII). As it is very difficult to suggest the possible measures to each and every delay cause lies in questionnaire, so attempts are made to suggest possible measures to those causes, which are extremely significant and pertains maximum contribution as a delay factor. In this study the causes which are mainly lies in Group-I are mainly considered for study, as they contributes towards $75 \%$ in overall delay in transportation infrastructure projects along with increased project duration and resulting increased project cost .
Table 1: Group based on RII

\begin{tabular}{|l|l|l|l|l|l|}
\hline RII & $\geq$ & $\begin{array}{l}0.601 \\
\text { to } \\
0.749\end{array}$ & $\begin{array}{l}0.350 \\
\text { to } \\
0.600\end{array}$ & $\begin{array}{l}0.250 \\
\text { to } \\
0.349\end{array}$ & $\begin{array}{l}0.100 \\
\text { to } \\
0.249\end{array}$ \\
\hline Group & $I$ & $I I$ & $I I I$ & $I V$ & $V$ \\
\hline
\end{tabular}

\section{RESEARCH FINDING AND RESULTS}

\subsection{General Opinions of Respondents:}

Respondent's opinion about the contribution towards the delay is explained in following paragraph. According to that, $50 \%$ respondent feels that delay in the construction in mainly due to the contractor. $40 \%$ of respondent feel that client is mainly responsible for the delay in construction projects. And only 10 $\%$ of respondent feel that delay mainly occur due to consultant. It seems that the problem is common and notable as $72 \%$ of the total infrastructure projects reported by all the respondents were delivered late, whereas only $28 \%$ were completed on time. Clients' respondents indicated that $59 \%$ of the public projects they were involved in were delivered late. Consultants' respondents reported that $62 \%$ of the projects they were involved in were completed late. Contractors' respondents also share the same view and articulated that $77 \%$ of the projects they are involved in exceeded the preset duration. Chart No. 2 shows the data collected from the parties regarding the lateness in delivering the public projects they were involved.

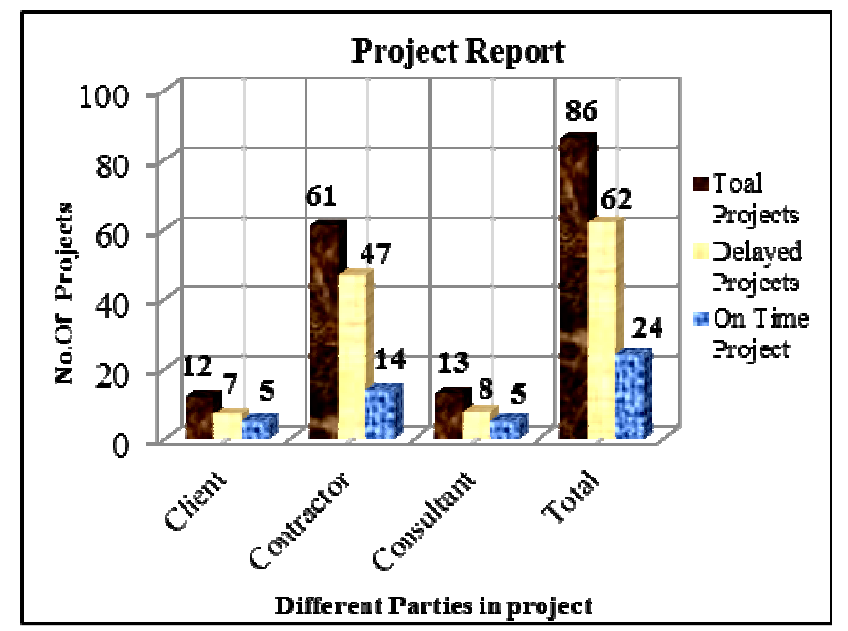

Chart-2 Delays faced by different parties in Projects

As far as overall ranking of all causes are considered, the five causes are identified in first group of RII as we have discussed in last chapter. Cause no.11 'Delay due to land acquisition' stands on first rank with RII (0.900), from the second stage i.e Project planning and main procurement. Cause no. 1'Environmental issues related with project' stands on second rank with RII (0.860), from the first stage feasibility and early 
planning .Cause no.03 'financial closure' stands on third rank with RII ( 0.840 ), from the first stage feasibility and early planning. Cause no. 30 'change orders by client' stands on fourth rank with RII (0.800) from third stage, contract execution monitoring and control, client group. Cause no. 40 'Poor site management and supervision by contractor' stands on fifth rank with RII (0.780) from third stage contract execution and monitoring and control, contractor group. Table no. 2 shows the ranking of all other remaining causes.

\subsection{Ranking of Causes of delay:}

Table 2: Ranking of Causes of Delay

(Contr-Contractor, Conslt./Designr-Consultant/Designer, Ext.- External Factors)

\begin{tabular}{|c|c|c|c|c|}
\hline $\begin{array}{l}\text { Sr. } \\
\text { No }\end{array}$ & Delay Causes & RII & $\begin{array}{c}\operatorname{Ran}_{\mathbf{k}} \\
\end{array}$ & Party \\
\hline 1 & $\begin{array}{l}\text { Delay Due to Land } \\
\text { Acquisition }\end{array}$ & 0.900 & 1 & Owner \\
\hline 2 & $\begin{array}{l}\text { Environmental issues } \\
\text { related with project }\end{array}$ & 0.860 & 2 & Owner \\
\hline 3 & financial closure & 0.840 & 3 & Owner \\
\hline 4 & $\begin{array}{l}\text { Change orders by the } \\
\text { client }\end{array}$ & 0.800 & 4 & Owner \\
\hline 5 & $\begin{array}{l}\text { Poor site management } \\
\text { and supervision by } \\
\text { contractor }\end{array}$ & 0.780 & 5 & Contr. \\
\hline 6 & $\begin{array}{l}\text { Delay in progress } \\
\text { payments by client }\end{array}$ & 0.740 & 6 & Owner \\
\hline 7 & $\begin{array}{l}\text { Difficulties in obtaining } \\
\text { work permits }\end{array}$ & 0.740 & 7 & Owner \\
\hline 8 & $\begin{array}{l}\text { Inadequate planning \& } \\
\text { scheduling of contractor }\end{array}$ & 0.720 & 8 & Contr \\
\hline 9 & $\begin{array}{l}\text { Poor co-ordination } \\
\text { between contractor \& } \\
\text { other parties }\end{array}$ & 0.700 & 9 & Contr \\
\hline 10 & $\begin{array}{l}\text { Slow response from the } \\
\text { consultant to contractor } \\
\text { inquiries }\end{array}$ & 0.700 & 10 & $\begin{array}{l}\text { Conslt./ } \\
\text { Designr }\end{array}$ \\
\hline 11 & Encroachment problems & 0.680 & 11 & Owner \\
\hline 12 & $\begin{array}{l}\text { Poor qualification of the } \\
\text { contractors technical } \\
\text { staff }\end{array}$ & 0.680 & 12 & Contr \\
\hline 13 & $\begin{array}{l}\text { Differing site (ground) } \\
\text { conditions }\end{array}$ & 0.640 & 13 & Ext. \\
\hline 14 & $\begin{array}{l}\text { Effect of social and } \\
\text { cultural factors }\end{array}$ & 0.640 & 14 & Ext. \\
\hline 15 & $\begin{array}{l}\text { Lack of high-technology } \\
\text { mechanical equipment }\end{array}$ & 0.640 & 15 & Contr \\
\hline 16 & $\begin{array}{l}\text { Insufficient data } \\
\text { collection and survey } \\
\text { before design }\end{array}$ & 0.640 & 16 & Owner \\
\hline 17 & $\begin{array}{l}\text { Slowness in decision } \\
\text { making process by client }\end{array}$ & 0.620 & 17 & Owner \\
\hline
\end{tabular}

\begin{tabular}{|c|c|c|c|c|}
\hline $\begin{array}{l}\text { Sr. } \\
\text { No }\end{array}$ & Delay Causes & RII & $\begin{array}{c}\operatorname{Ran} \\
\mathbf{k}\end{array}$ & Party \\
\hline 18 & $\begin{array}{l}\text { Subsurface site } \\
\text { conditions materially } \\
\text { differing from contract } \\
\text { documents }\end{array}$ & 0.620 & 18 & Owner \\
\hline 19 & $\begin{array}{l}\text { Government tendering } \\
\text { system requirement of } \\
\text { selecting the lowest } \\
\text { bidding contractor }\end{array}$ & 0.620 & 19 & Owner \\
\hline 20 & $\begin{array}{l}\text { Delay in approving } \\
\text { major changes in the } \\
\text { scope of work by } \\
\text { consultant }\end{array}$ & 0.600 & 20 & $\begin{array}{l}\text { Conslt./ } \\
\text { Designr }\end{array}$ \\
\hline 21 & $\begin{array}{l}\text { Delay to transfer the site } \\
\text { to the contractor by the } \\
\text { client }\end{array}$ & 0.600 & 21 & Owner \\
\hline 22 & $\begin{array}{l}\text { Delay in performing } \\
\text { inspection and testing by } \\
\text { consultant }\end{array}$ & 0.600 & 22 & $\begin{array}{l}\text { Conslt./ } \\
\text { Designr }\end{array}$ \\
\hline 23 & $\begin{array}{l}\text { Shortage of manpower } \\
\text { (skilled, semi-skilled, } \\
\text { unskilled labour) }\end{array}$ & 0.580 & 23 & Contr \\
\hline 24 & $\begin{array}{l}\text { Poor co-ordination by } \\
\text { owner \& other parties }\end{array}$ & 0.580 & 24 & Owner \\
\hline 25 & $\begin{array}{l}\text { Ambiguities, mistakes, } \\
\text { and inconsistencies in } \\
\text { contract specifications } \\
\text { and drawings }\end{array}$ & 0.560 & 25 & Owner \\
\hline 26 & $\begin{array}{l}\text { Accident during } \\
\text { construction }\end{array}$ & 0.560 & 26 & Ext. \\
\hline 27 & $\begin{array}{l}\text { Delays due to Improper } \\
\text { Execution of the work by } \\
\text { contractor }\end{array}$ & 0.540 & 27 & Contr \\
\hline 28 & $\begin{array}{l}\text { Changes in material } \\
\text { types and specifications } \\
\text { during construction by } \\
\text { client }\end{array}$ & 0.540 & 28 & Owner \\
\hline 29 & $\begin{array}{l}\text { Changes in government } \\
\text { regulations and laws }\end{array}$ & 0.540 & 29 & Owner \\
\hline 30 & $\begin{array}{l}\text { Delays in drawings and } \\
\text { other approvals }\end{array}$ & 0.520 & 30 & Owner \\
\hline 31 & $\begin{array}{l}\text { Conflicts between } \\
\text { contractor and other } \\
\text { parties (consultant \& } \\
\text { owner) }\end{array}$ & 0.520 & 31 & Contr \\
\hline 32 & $\begin{array}{l}\text { Shortage of technical } \\
\text { professionals in the } \\
\text { Clients organization }\end{array}$ & 0.520 & 32 & Owner \\
\hline 33 & $\begin{array}{l}\text { Delay in timely } \\
\text { mobilization by the } \\
\text { contractor }\end{array}$ & 0.520 & 33 & Contr \\
\hline 34 & $\begin{array}{l}\text { Poor coordination } \\
\text { between consultant and } \\
\text { other parties }\end{array}$ & 0.500 & 34 & $\begin{array}{l}\text { Conslt./ } \\
\text { Designr }\end{array}$ \\
\hline
\end{tabular}




\begin{tabular}{|c|c|c|c|c|}
\hline $\begin{array}{l}\text { Sr. } \\
\text { No }\end{array}$ & Delay Causes & RII & $\begin{array}{c}\operatorname{Ran}_{\mathbf{k}} \\
{ }^{2}\end{array}$ & Party \\
\hline 35 & $\begin{array}{l}\text { Delay in ordering main } \\
\text { equipment by contractor }\end{array}$ & 0.500 & 35 & Contr \\
\hline 36 & $\begin{array}{l}\text { Changes in materials } \\
\text { prices }\end{array}$ & 0.500 & 36 & Ext. \\
\hline 37 & $\begin{array}{l}\text { Rework due to errors } \\
\text { during construction by } \\
\text { contractor }\end{array}$ & 0.480 & 37 & Contr \\
\hline 38 & $\begin{array}{l}\text { Effects of subsurface } \\
\text { conditions (e.g., soil, } \\
\text { high water table, etc.) }\end{array}$ & 0.480 & 38 & Ext. \\
\hline 39 & $\begin{array}{l}\text { Uncooperative client } \\
\text { with the contractor } \\
\text { complicating contract } \\
\text { administration }\end{array}$ & 0.480 & 39 & Owner \\
\hline 40 & $\begin{array}{l}\text { Inadequate experience of } \\
\text { consultant }\end{array}$ & 0.480 & 40 & $\begin{array}{l}\text { Conslt./ } \\
\text { Designr }\end{array}$ \\
\hline 41 & $\begin{array}{l}\text { Unrealistic imposed } \\
\text { initial contract duration }\end{array}$ & 0.460 & 41 & Owner \\
\hline 42 & Low skill of manpower & 0.460 & 42 & Contr \\
\hline 43 & $\begin{array}{l}\text { Inadequate design-team } \\
\text { experience }\end{array}$ & 0.460 & 43 & $\begin{array}{l}\text { Conslt./ } \\
\text { Designr }\end{array}$ \\
\hline 44 & $\begin{array}{l}\text { Legal disputes between } \\
\text { various parts }\end{array}$ & 0.440 & 44 & $\begin{array}{l}\text { Owner/ } \\
\text { Contr. }\end{array}$ \\
\hline 45 & $\begin{array}{l}\text { Late in reviewing and } \\
\text { approving design } \\
\text { documents during } \\
\text { construction by } \\
\text { consultant }\end{array}$ & 0.440 & 45 & $\begin{array}{l}\text { Conslt./ } \\
\text { Designr }\end{array}$ \\
\hline 46 & $\begin{array}{l}\text { Rehabilitation of } \\
\text { affected people }\end{array}$ & 0.440 & 46 & Owner \\
\hline 47 & $\begin{array}{l}\text { Delays in contractor's } \\
\text { payments to } \\
\text { subcontractors }\end{array}$ & 0.420 & 47 & Contr \\
\hline 48 & $\begin{array}{l}\text { Appointment of } \\
\text { incompetent } \\
\text { Consultant/Contractor }\end{array}$ & 0.420 & 48 & Owner \\
\hline 49 & $\begin{array}{l}\text { Low productivity level } \\
\text { of labors }\end{array}$ & 0.420 & 49 & Contr \\
\hline 50 & Equipment breakdowns & 0.420 & 50 & Ext. \\
\hline 51 & $\begin{array}{l}\text { Force majeure( Acts of } \\
\text { god ) extreme weather } \\
\text { ( hot /cold ) and unusual } \\
\text { rain, typhoon floods, } \\
\text { landslides and } \\
\text { earthquake }\end{array}$ & 0.400 & 51 & Ext. \\
\hline 52 & $\begin{array}{l}\text { Inadequate equipment } \\
\text { used for the works }\end{array}$ & 0.400 & 52 & Contr. \\
\hline 53 & $\begin{array}{l}\text { Complexity of project } \\
\text { design }\end{array}$ & 0.380 & 53 & $\begin{array}{l}\text { Conslt./ } \\
\text { Designr }\end{array}$ \\
\hline 54 & $\begin{array}{l}\text { Delay in manufacturing } \\
\text { special building } \\
\text { materials }\end{array}$ & 0.380 & 54 & Ext. \\
\hline
\end{tabular}

\begin{tabular}{|c|l|c|c|c|}
\hline $\begin{array}{c}\text { Sr. } \\
\text { No }\end{array}$ & \multicolumn{1}{|c|}{ Delay Causes } & RII & $\begin{array}{c}\text { Ran } \\
\mathbf{k}\end{array}$ & Party \\
\hline 55 & Shortage of equipment & 0.380 & 55 & Ext. \\
\hline 56 & $\begin{array}{l}\text { Severe weather } \\
\text { conditions on the job site }\end{array}$ & 0.360 & 56 & Ext. \\
\hline 57 & $\begin{array}{l}\text { Late in reviewing and } \\
\text { approving initial design } \\
\text { documents by consultant }\end{array}$ & 0.340 & 57 & $\begin{array}{l}\text { Conslt./ } \\
\text { Designr }\end{array}$ \\
\hline 58 & $\begin{array}{l}\text { Safety rules and } \\
\text { regulations are not } \\
\text { followed within the } \\
\text { contractor's organization }\end{array}$ & 0.340 & 58 & Contr \\
\hline 59 & $\begin{array}{l}\text { Shortage of construction } \\
\text { materials in market }\end{array}$ & 0.320 & 59 & Ext. \\
\hline 60 & $\begin{array}{l}\text { Suspension of work by } \\
\text { the client's organization }\end{array}$ & 0.300 & 60 & Owner \\
\hline 61 & $\begin{array}{l}\text { Traffic control and } \\
\text { restrictions on the job } \\
\text { site }\end{array}$ & 0.280 & 61 & Ext. \\
\hline 62 & $\begin{array}{l}\text { Unclear and inadequate } \\
\text { details in drawings }\end{array}$ & 0.280 & 62 & $\begin{array}{l}\text { Conslt./ } \\
\text { Designr }\end{array}$ \\
\hline 63 & $\begin{array}{l}\text { Work hours are limited } \\
\text { by imposed rules or site } \\
\text { condition }\end{array}$ & 0.260 & 63 & Ext. \\
\hline $\begin{array}{l}\text { Delay in providing } \\
\text { services from utilities } \\
\text { (such as water, } \\
\text { electricity) }\end{array}$ & 0.240 & 64 & Owner \\
\hline
\end{tabular}

\subsection{Ranking of Groups:}

As overall ranking of stages in concern, stage one 'Feasibility and early planning' stands on first rank with RII (0.604). 'Project planning and main procurement' stage stands on second place with RII (0.570). Third rank hold by stage three i.e 'Contract execution monitoring and control with RII (0.496).

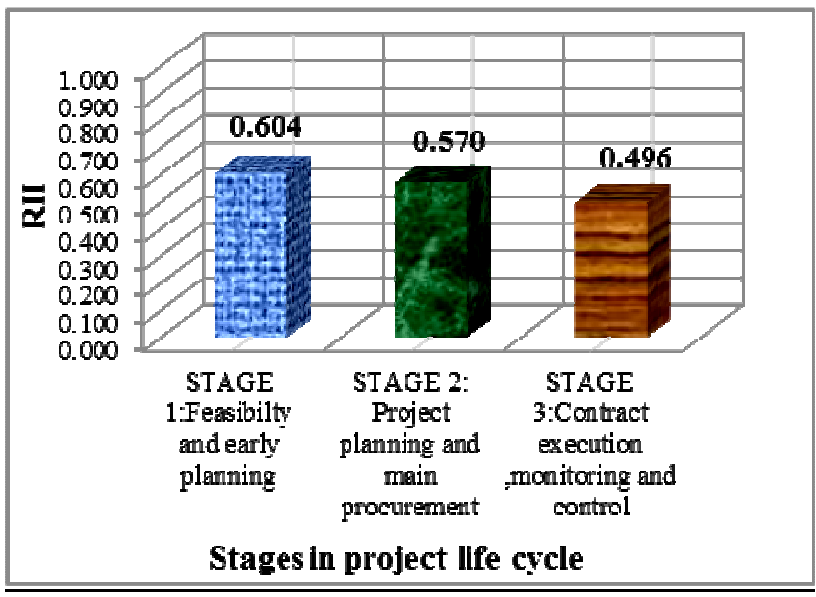

Chart-3 Ranking of Stages 


\subsection{Ranking of Group in Stage Three:}

As far as ranking of all the groups in third stage is concern there are mainly seven groups are identified and ranked .According to respondent overall opinion in each cause in every group the client related group stands on rank one with RII (0.577) in third stage. While contractor's group stands on second rank with RII (0.576) very close to client related group. Besides that consultant and designer related group stands on third rank with RII (0.508). With RII (0.487) manpower related group stands on fourth rank. Equipment related group stands on fifth rank with RII (0.460).Material and external factor related group stands on sixth and seventh rank with RII (0.435) and (0.429) respectively.

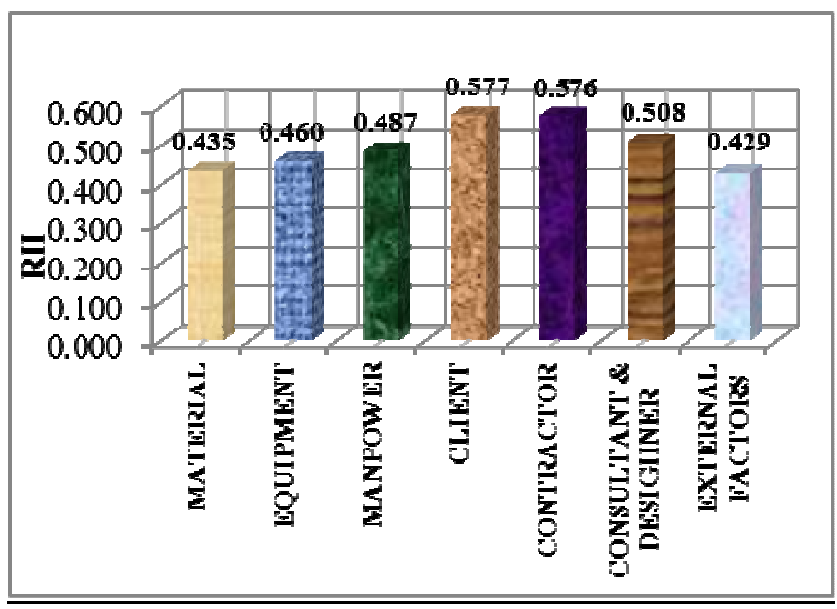

Chart-4 Ranking of group in Stages three.

\section{DISCUSSION OF RESULTS:}

As far as questionnaire survey is concern $90 \%$ of respondent feels that, delay due to land acquisition may be the main cause leading delay in transportation infrastructure and having highest Relative Importance Index 0.900. According to questionnaire survey $90 \%$ of respondent reply that, this cause certainly increases project completion time. Work acceleration may be necessary; even then overall construction time exceeds and may also affect total project cost. In India, land acquisition is major cause of delay in any project. The land acquisition procedure is followed under the Land Acquisition Act, to acquire land compulsorily when it is to be used for public purpose. However, invariably the locals whose land is to be acquired don't easily part with their land due to the following issues: Ancestral land has a lot emotional feelings attaches to it. The owner may not find it easy to part with such property. The land may be the owner's only source of income. If the owner feel the amount given as compensation for the land is insufficient then he may not easily concede the land. Interpersonal inequities: When an area of particular size is acquired, it happens so that after the land has been put to use, the value of the surrounding land increases substantially. This has been observed by the people on several occasions and therefore no owner freely concedes his land fearing that, he may lose out on the increased value of land at a later stage. This is known as 'Interpersonal Inequities'. This is often the single most issue that delays the land acquisition process.

According to questionnaire survey, delay due to environmental issues related with project ranked at second place with Relative Importance Index 0.860. $90 \%$ respondent said that due to this reason total Construction time is affected .Work acceleration may be necessary; even then overall construction time exceeds and may also affect total project cost. Almost every developmental activity has some negative impact on the environment. The impact, however, differs according to the nature of activity. Thus, whereas setting up an industrial unit can have serious impact on the water and air quality besides affecting the flora and fauna of the area. A transportation project can dramatically push up the noise and pollution level of the surrounding areas. It is with the purpose of containing the potential negative impacts of a development projects that the Environment Impact Assessment is done. Thus, it can be stated that Environmental Impact Assessment (EIA) is one of the tools available for planners to minimize and contain harmful effects of the development activity on the environment. The objective of an EIA is to foresee and address potential environmental problems/concerns at an early stage of project planning and design. This is a decisionmaking tool to ensure that finite natural resources are utilized within the carrying capacity of the eco-system to avoid its collapse. Environment clearances take away hell lot of a time of corporate as projects for expansion and modernizations including new projects have to pass through over 36 channels at state and central levels before being finalized. On top of this political financial commitment clearances are also needed as some of the projects involving thousands of crores of investments need to be cleared off strategically, said over 70 per cent of business leaders whose opinion were sought in this regard. People must realize that where the all-important issues of a city's collective health and quality of life are concerned, a clean environment is more important and relevant consideration than that of the smooth traffic flows which reduce commuting time.

According to questionnaire survey this cause is ranked at third place with relative importance index of 0.840 . Again $90 \%$ of the respondents feel that this is the cause due to which most of the projects get delayed with an about 60 to $70 \%$ contribution also work acceleration may be necessary; even then overall construction time exceeds and may also affect total project cost. The Government of India has very ambitious for development of infrastructure in the country. It has been estimated that an investment of nearly $\$ 1$ trillion would be required in order to achieve the kind of targets the govt. is aiming for. However the toughest aspect is how to arrange funds of such magnitude. Many projects are getting delayed 
precisely because of this reason. Many transportation projects are stuck in the fund raising stage itself, because it is very difficult to achieve complete financial closure. To ease the pressure on the government treasury the government has initiated new models such the Public Private Partnership (PPP). It was found that it would be almost impossible for the government to finance the infrastructure projects of such scale. It was thought that the involvement of Private players will help loose the burden over the govt. as well as it benefit to those private players who are responsible for huge growth of the infrastructure sector in general. The government, when it started this model expected that with the involvement of private players it would be relatively easy to achieve financial closure. The nature of the projects also changed and many projects became BOOT or Turnkey based projects, but even this model was not entirely successful. The private players alleged that the internal rate of return (IRR) of many projects was less than the benchmark they had set (usually around $8 \%$ ). Hence they were hesitant to invest in such projects. However, the government then came up with a concept of Viability Gap Funding (VGF). In this the government announced that the gap due to less Internal Rate of Return (IRR) will be funded by the government. This encouraged many more private players to enter into Public Private Partnership (PPP).

According to questionnaire survey $70 \%$ respondent feel that this cause having 60 to $70 \%$ contribution to project delay with Relative importance index of 0.800 and ranked on fourth place. $20 \%$ of the respondent feel that, this cause contribute 35 to $60 \%$ overall delay in project. But his delay can be adjusted within construction time. The utility of an infrastructure investment hinges upon the timely delivery of the built facility within budget. In most public works, changes have contributed to the main cause of construction delay and cost overrun. Changes also produce a multitude of other negative impacts, such as low morale, quality discrepancies, and legal disputes. According to literature and practical experience, the causes for change orders are greatly varied, thus the task of dealing with often changing management is difficult for most clients. Because of various constraints, perfect design is unrealistic, and thus design changes are inevitable. In cases where changes are required, responding to changing environmental or project needs requires issuing a change order (C.O.). While causes to change order may pertain to common knowledge in field, effective management of change order is less seen, particularly in a large-scale project.

According to questionnaire survey this cause is ranked on fifth place with relative importance index of 0.780 . From this it is clear that, $70 \%$ of respondent feel that this cause contribute 60 to $70 \%$ of overall delay in project. But this delay can be minimized with different work acceleration methods. Many a time, reputed contracting firms also find themselves in such a situation where the impending work is delayed because the previously executed part of the work is not up to the required standard and further work cannot be carried out before the problems are sorted. In most of such cases the problem solely lies with improper supervision of the work and adopting wrong methods of construction. Workmanship sometimes is of poor order and can contribute to such problems. These types of delays are very much avoidable but in the Indian scenario it is noteworthy that the contracting firms have a lackadaisical approach towards the execution of the work using the correct methodology and practices. On many occasions previously applied indigenous methods for a particular scenario may not hold good for another situation. However due lack of understanding of the methodology leads the contractor to apply the same method for all situations. This may cause a delay in the project which is totally unwarranted.

\section{CONCLUSIONS}

This study aims to investigate the important causes of delay in transportation infrastructure projects. The literature is reviewed thoroughly and a questionnaire which contains sixty four possible causes of construction delays in transportation infrastructure projects is formed. The results revealed that the problem of construction delays in transportation infrastructure projects is frequent and notable. The top five important causes of construction delays in transportation infrastructure projects are mainly Land Acquisition, Environmental Impact of the project, financial closure, Change orders by the client, Poor site management and supervision by contractor. It is evident that consultant as a mediator has less responsibility in construction delays. As far as effect of delay is concern, most of the respondents feel that it results in the time overrun. Cost overrun is also evident as an effect of delay as a second choice of the respondent. Mainly delay in infrastructure projects are occurred in the first stage i.e. feasibility and early planning stage as compare to that of construction. As top twenty severe causes are considered, five causes originate from the group of client, for ex., financial closure, change orders, delay in progressive payment, slowness in decision making and faulty contract documents. Five causes originate from the group of contractors such as poor site management and supervision by contractor, poor coordination between contractor and other parties, inadequate planning and scheduling of contractor, poor qualification of contractor's technical staff and lack of using high technology mechanical equipment etc. Three causes originate from the group of consultants and designers and are slow response of consultant to contractor's inquiries, insufficient data collection before design, delay in approving major changes in the scope of work by consultant etc. Some of the causes are to be addressed are beyond the control of all the project parties such as differing site conditions, social and cultural factors related with projects etc. Talking about the overall responsibility of delay over different groups, client and contractor possesses near about same Relative Importance Index. So both are equally responsible for overall delay in construction projects. After conducting the questionnaire survey and interviews, following are some key points to be 
addressed to minimize construction delay in transportation infrastructure projects.

Due to the fact that acquiring land for construction project is one of the major hurdles in creating infrastructure. Every country has its own historical problems and land acquisition never was an easy issue to be solved. Some changes are to be addressed in current legislation to facilitate ease in land acquisition such as, clear definition of 'Public Purpose' in Land Acquisition Act, mandatory provision for rehabilitation in prescribed time limit, monetary compensation by rapid procedure and appointment of commission to deal all affairs as one window programme etc. The client/ government should ideally have available $70 \%-80 \%$ of the land required for a project before inviting bids from interested parties, something that in reality never happens.

Environmental issues have become one of the key factors of delay in construction projects. India being a rapidly developing country will quickly have to find a balance between the environmental concerns and the development of mega projects. It cannot be so that these concerns can be neglected totally. However, environmental issues should not become a hurdle in the development of mega projects. It is expected that this would translate into greater flexibility. In order to save time there should be one or more empowered comities consisting of secretaries or senior officers from concerned ministries which may give some necessary clearances.

Financing the project is a Herculean task and the present liquidity squeeze in the financial sector has only made things more difficult. The government has recognized this issue albeit belatedly and is now following models like the PPP on a regular basis to avoid financial crunch. It is encouraging to know that the government is contemplating the role that foreign direct investment (FDI) would play in financing these projects. Another issue is, government opines that there is a shortage of investment in infrastructure and on the other hand the funds which were allocated for infrastructure sector are not even utilized. These hints at improper management of funds and the government can do well to use existing resources more efficiently. Thus allocation of sufficient money/ funds for good highway/roads construction, rehabilitation, maintenance and repair must not be ignored. At least this allocation must be equivalent to transport revenue or otherwise policy of ignoring roads will prove fatal for the Nation.

As far as possible changes should be the last option from both client as well as contractor. Scope should be well defined such that no alterations are required either addition or deletion. From the case study and literature review it is clear that, most of the changes are required to be made during construction phase due to improper feasibility study. So attempts are to be made as the project shall be planned and designed after carrying out all necessary investigations so that changes in project features do not occur during construction and if at all they occur, they are not of much significance.

Many Indian contractors in some cases have not been able to cope up with this rapid change in the nature of the projects. However, there are some contracting firms which have adopted themselves to the changed scenario and this augurs well for the future. There should be frequent arrangement of training programmes to cope with the changing environment of construction industry to improve their managerial techniques. It should be mandatory for those contracting firms which are new in the infrastructure projects or mega projects. This training should be in coordination with firms which have successfully completed the infra projects in our country and also at abroad. In India unfortunately we have taken for granted that delays in transport projects are a certainty. This attitude within the construction fraternity must change. We have shining examples of projects like the Delhi metro, Hyderabad airport and Konkan railway which have been completed on time. This means that it is a question of will and determination which if present can achieve great results. With India well on the march to achieve greatness, it will be slowly but surely wake up to these challenges and emerge stronger.

\section{RECOMMENDATION}

\subsection{General Recommendations}

1. As there is a penalty applied to those contractors who fail to deliver projects on time, it is also important to maintain incentives for those who deliver projects ahead, within budget and with super quality.

2. As in the manufacturing industry an annual prize is given to the best factory, similar idea should be implemented in the construction industry.

3. The Indian construction industry lacks the research and development and the government should encourage and support such strategies.

4. It is recommended to establish of a governmental authority which concerns with developing the Omani construction industry and tackles the obstacles that are facing it.

5. It is important to reconsider the governmental strategies that encourage the selection of the lowest bidding contractors and to improve the routine procedures and requirements that are required for obtaining work permits.

\subsection{Recommendations to Client}

As client is the main party on the construction process, he/she is required to effectively participate in the improving the situation. The following advices are important for clients to ensure improvements in delivering projects on time:

1. More attention should be taken during the planning and design stages to ensure a well-defined scope and minimize any future changes in scope during the construction stage. 
2. It is important to define the decision making process within the client organization and eliminate any tasks within that process that do not add any value "wastes".

3. Clients should have experienced and qualified personals that facilitate the construction process to avoid delays resulting from late approvals.

4. Clients are encouraged to select contractors and consultants carefully based on a combination of technical and financial criteria and not only based on the lowest price.

5. Clients are strongly advised to pay contractors on time as contractors are severely affected by delays in payments.

6. Clients should make sure the site is available for the contractor to start the construction activities and any restrictions such as local relocation should be tackled prior to construction.

\subsection{Recommendations to Contractor}

Contractors are also required to participate in the improvement revolution and the following actions are recommended:

1. Contractors should not bid for contracts unless they are confident of their capabilities to perform the work involved successfully.

2. Contractors are required to maintain a sound quality management and avoid any rework due to poor quality as it is costly and causes construction delays.

3. Contractors should ensure the availability and the well management of all resources such as workforce, materials and equipment to avoid any work disruption.

4. All submittals should be submitted on the required time and in a proper way to avoid any construction delays due to difficulty of approving these submittals.

5. The contractor should focus on the development of the workforce and to maintain a permanent and cohesive team which is fully satisfied with the environment they are working in to ensure good communications and motivation.

\subsection{Recommendations to Consultant}

Consultants also share the responsibility in minimizing the construction delays although they are not highly accused of such delays. The followings are recommended for the consultants:

1. Consultants should work as a facilitator of the construction process and should change the strategy of chasing mistakes.

2. Consultants should react positively to contractors' inquiries and submittals and should also prepare any required drawings on the required time.

3. Consultants should take in consideration to employ qualified and experienced personals that are able to manage the construction site properly.

\section{REFERENCES}

[1] Ayman H. and Al-Momani, "Construction delay: a quantitative analysis", International Journal of Project Management, Vol.18, No.2, 2000, PP 51-99.

[2] Daniel W M Chan and Mohan M. Kumaraswamy, "Comparative study of causes of time overruns in Hong Kong construction projects" ,International Journal of Project Management Vol. 15, No. 1, 1997,PP. 55-63

[3] Noulmanee A, Wachirathamrojn J, Tantichattanont P, Sittivijan P. Internal causes of delays in highway construction projects in Thailand. www.ait.clet.com, July, 1999.

[4] Ubaid AG. Factors affecting contractor performance. Master thesis,CEM Dept., KFUPM, Dhahran, Saudi Arabia, 1991.

[5] Ram Singh, "Delays and Cost Overruns in Infrastructure Projects: Extent, Causes and Remedies", Economic and Political Weekly, Vol.21. May 22, 2010, PP 43-54.

[6] Ministry of Statistics and Programme Implementation (MOSPI), Project Implementation Status Report of Central Sector Projects, April-June, 2009.

[7] Murali Sambasivan and Yau Wen Soon, "Causes and effects of delays in Malaysian construction industry" International Journal of Project Management, Vol.25, No.2, 2007, PP 517-526

[8] Sadi A. Assaf and Sadiq Al-Hejji, "Causes of delay in large construction projects", International Journal of Project Management, Vol.24, 2006, PP349-357.

[9] Theodore J. Trauner, Jr., P.E., P.P., William A. Manginelli, J. Scott Lowe, P.E., Mark F. Nagata and Brian J. Furniss, "Construction delay", Elsevier publication, second edition., PP 21-25

\section{BIOGRAPHIES}

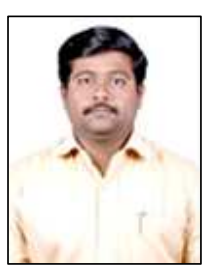

Suraj Patil has received the B.E. and M.E. degree in Civil Engineering from Shivaji university Kolhapur in year 2009 \& 2013 respectively. From year 2010 onwards he is working as an Assistant Professor in Dr.J.J.Magdum College of Engineering Jaysingpur. He has presented 04 papers in international conference and published 03 papers in International journal.

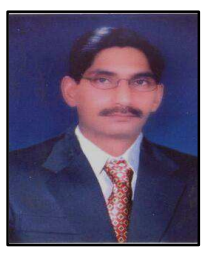

Anilkumar Gupta has received the B.E. and M.E. degree in Civil Engineering from Shivaji university Kolhapur in year 1994 \& 2000 respectively. He has submitted Phd thesis in year 2012. From year 1994 onwards he is working as a Professor and Vice-Pricipal in Dr.J.J.Magdum College of Engineering Jaysingpur. He has also having 19 year wide teaching experience. He published 23 papers in international journal .He has also presented 9 papers in international conference. 
Anilkumar Gupta has guided 11 students for their Master Degree in engineering.

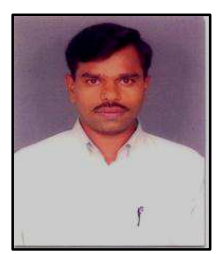

Dadaso Desai has received the B.E. and M.E. degree in Civil Engineering from Shivaji university Kolhapur in year 1994 \& 2006 respectively. From year 1995 onwards he is working as a Asso.Professor in Dr.J.J.Magdum College of Engineering Jaysingpur. He has also having 18 year wide teaching experience. He published 11 papers in international journal. He has also presented 12 papers in international conference. Dadaso Desai has guided 18 students for their Master Degree in engineering

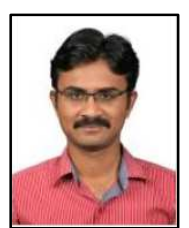

Amitkumar Sajane has received the B.E. and M.E. degree in Civil Engineering from Shivaji University Kolhapur in year 2006 \& 2010 respectively. From year 2009 onwards he is working as an Assistant Professor in Dr.J.J.Magdum College of Engineering Jaysingpur. He has having 03 international conference and 04 journal papers 